\title{
Geohistory of Tso-Morari Crystalline, Eastern Ladakh, India: a plausible model for ultra-high pressure rocks in the Himalaya
}

\author{
Ram S. Sharma \\ 70/36 Pratap Nagar, Shohpur Road, Jaipur-303906, INDIA \\ E-mail:sharma.r.sw@gmail.com
}

The Tso-Morari Crystalline (TMC), eastern Ladakh, is located between the ophiolitic rocks of the Indus-Tsangpo Suture Zone (ITSZ) in the north and the Zanskar sedimentary unit (Tethyan sedimentary zone) in the south. The TMC represents the northern Himalayan Crystalline. It is composed of quartzo-feldspathic gneiss, mostly augen-gneiss, derived from granitoids. Associated with these gneisses are the biotite schist and sillimanite-kyanite gneiss, which occur as discontinuous metasedimentary layers concordant with the banding of the gneisses. The Tso-Morari gneiss complex is heterogeneously deformed and show magmatic to mylonitic texture with dominant S-surface that is domed by NW-SE antiform. The TMC gneisses form the core of this vast dome. The Tso-Morari dome plunges in the west under metasediments, mainly garnet-bearing metapelites of the Phe or Haimanta Formation (Precambrian to Cambrain age). The U$\mathrm{Pb}$ isotope on zircons, single grain as well as small multigrain fractions from the gneiss (deformed granite) yielded magmatic age of $479 \pm 2 \mathrm{Ma}$ (Girard and Bussy 1999). Similar age is also reported in the nearby located Polokongla granite. The transition between the Polokongla granite and the Tso-Morari gneiss is gradual, devoid of any intrusive contact with the gneiss. This field occurrence together with their geochemical similarities, identical zircon morphology and same age, suggest that the Polokongla granite is the undeformed facies of the Tso-Morari gneiss. Other granite in the terrain is the Rupshu metagranite which is metaluminous with $\mathrm{U}-\mathrm{Pb}$ zircon age of $482.5 \pm 1 \mathrm{Ma}$ (Girard and Bussy 1999). Strikingly, there are no aplite or pegmatite dykes related to the granite-gneiss association in the TMC terrain. The Tso-Morari gneiss complex encloses eclogitic lenses (1-13 m long and 0.5-4 $\mathrm{m}$ thick), aligned parallel to the gneissic fabric. The eclogites, mostly retrograded, are scattered throughout the complex. They are found mainly within the Tso-Morari gneiss and also in the first few hundred meters of metasediments above, which prompted Steck et al. (1998) to designate the Tso-Morari complex as Tso-Morari Nappe - a tectonic unit of high pressure metamorphism. Because of the eclogitic lenses within the TsoMorari dome, it is obvious that the high pressure metamorphism also affected the Tso-Morari gneisses. The garnet (45-55 vol.\%) in the eclogites is rimmed by glaucophane (5-7 vol.\%) paragonite $(<10 \%)$, and omphacite $(25-35 \%)$. These minerals also form matrix in the eclogitic rock (Sachan et al., 1999). Glaucophane is also surrounded by tremolite-actinolite as retrogression products (De Sigoyer et al. 1997). In some eclogites, the garnet core contains inclusion of quartz, quartz-coesite or coesite only (Sachan et al. 2004), suggesting coesite formation from quartz during subduction. The eclogite garnets invariably show chemical zoning with $\mathrm{Mg}$ increasing and Fe decreasing from core to rim (Sachan et al. 2004). This cation profile of coestie-bearing garnet clearly suggests prograde nature of the ultra-high pressure metamorphism in the TMC unit. The occurrence of quartz to coesite from core to rim of the garnet together with the chemical zoning of garnet unambiguously suggest prograde nature of the ultra-high pressure metamorphism (UHP).

P-T conditions for the UHP metamorphism are estimated at $20 \pm 3 \mathrm{kbar}, 580 \pm 60^{\circ} \mathrm{C}$ for the Tso-Morari gneisses (De Sigoyer et al. 1997, Guillot et al. 1997, Sachan et al. 2004). The UHP metamorphism in the Tso-Morari area has been dated at $55 \pm 17 \mathrm{Ma}$ (U-Pb on allanite) and $55 \pm 12 \mathrm{Ma}$ (Lu-Hf on garnet-cpx-rutile) (De Signoyer et al. 2000). Analogous occurrence in the Kaghan valley, Pakistan, the eclogite yielded a $\mathrm{Sm} / \mathrm{Nd}$ age on garnet-cpx pair of 49 $\pm 6 \mathrm{Ma}$ (Tonarini et al. 1993). Eclogitization therefore occurred during subduction of the Indian plate beneath Asia.

From the field occurrence of eclogites (metamorphosed basalt) and the presence of coesite with or without quartz in silicate rocks and in pyrope rich garnet suggest rapid subduction of the Indian Precambrian crust to near $100 \mathrm{~km}$ depth. With continued subduction, when Indian continental landmass came to collision against Asia (45 - 50 Ma), Proterozoic to Lower palaeozoic cover sequences of northern Indian plate slipped under Asian plate and the Ladakh-Kohistan island arc. In this event, the oceanic lithosphere is assumed to have dragged down a hooked-component of the continental crust of the northern Indian plate margin to great depths, within the coesite stability field. Consequently, UHP mineral assemblages developed in silicate-bearing rocks, especially coesite in garnets (Mukherjee and Sachan 2007) and eclogites in the root of subducting plate. With the slab detachment in depth, the continent-continent collision of India-Asia terminated and the "sunkun" crustal rocks had a rapid return toward shallower depths enabling them to preserve their UHP mineralogy. This movement was akin to that experienced by the contestants in a tug of war with sudden breaking of the rope across the marking line. In the proposed slab-breakoff process, the subducted material possibly exhumed in form of varying-sized fragments (eclogite lenses) and emplaced in the TMC adjacent to ITSZ. It is believed that the Indian crust, which had subducted only to a limited depth owing to buoyancy, exhumed first as the recrystallized Tso-Morari crystalline that became the host rock for the next obducted material from greater depth, especially the eclogites. All the eclogite fragments within TsoMorari gneisses are characterized by incomplete transformation of coesite to quartz and by radial fractures around the silica inclusions within garnet (Sachan et al 2004), supporting rapid exhumation of the eclogites from depth of $>90 \mathrm{~km}$. The mechanism finds support from the occurrence of post-orogenic, undeformed basic rocks (as product of decompression melting of up-warped lithosphere) that intruded the Himalayan metamorphics at several places (Sharma 1962) and from the deep mantle anomalies recently discovered by seismic tomography at the base of lithosphere in West Pakistan (van der Voo et al. 1999). 


\section{References}

De Sigoyer J, S Guillot, JM Lardeaux, and G Mascle. 1997. Glaucophanebearing eclogites in the Tso-Morari dome (eastern Ladakh, NW Himalaya). Eur. J. Mineral. 9:1073-1083

De Sigoyer J, V Chavagnac, BJ Toft, IM Villa, B Luais, S Guillot, M Cosca and $\mathrm{G}$ Mascle. 2000. Dating the Indian continental subduction and collisional thickening in the northwest Himalaya: multichronology of the Tso-Morai eclogites. Geology 28: 487-490

Girard M and F Bussy. 1999. Late Pan-African magmatism in the Himalaya: new geochronological and geochemical data from the Ordovician Tso-Morari metagranites (Ladakh, NW India). Schweiz. Mineral. Petrogr. Mitt. 79: 399-418

Guillot S, J De Sigoyer, JM Lardeaux and GJ Mascle. 1997. Eclogitic metasediments from the Tso-Morari area (Ladakh, himalaya): evidence for continental subduction during India-Asia convergence. Contrib. Mineral. Petrol.128: 197-212

Mukherjee BK and HK Sachan. 2007. Tracing of Indian continental crust in the mantle and back: a semantic approach. Himalayan Geology 28(3): 21-22
Sachan HK, RJ Bodnar, R Islam, Cs Szabo and RD Law. 1999. Exhumation history of eclogits from Tso-Morari crystalline complex in eastern Ladakh: mineralogical and fluid inclusions constraints. J. Geol. Soc. India 53: 181-190

Sachan HK, BK Mukherje, Y Ogasawar, S Maruyama, H Ishida, A Muko and N Yoshioka. 2004. Discovery of coesite from Indus Suture Zone (ISZ), Ladakh, India: evidence for deep subduction. Eur. J. Mineral. 16:235-240

Steck A, JL Epard, JC Vannay, J Hunziker, M Girard, A Morard and M Robyr. 1998. Geological transect across the Tso Morari and Spiti areas: the nappe structures of the Tethys Himalaya. Eclogae, geol. Helv. 91: $103-121$

Sharma RS. 1962. On the occurrence of an olivine-dolerite laccolith at Ranikhet, dist. Almora (U.P.). Jour. Sci. Res. 12(2): 231-237

Tonarini S, IM Villa, F Oberli, M Meier, DA Spencer, U Pognante and J Ramsay. 1993. Eocene age of eclogite metamorphism in Pakistan Himalaya: implication for India-Eurasia collision. Terra Nova 5: 13-20

Van der Voo R, W Spakman and H Bizwaard. 1999. Tethyan subducted slab under India. Earth Planet. Sci. Lett. 171:7-20 